\title{
Scientific Story Writing Technique in the Alternative Assessment of the Subject of Liquids: The Sample of Science and Biology Teaching Students
}

\author{
Gamze Dolu ${ }^{1 *}$, Handan Ürek¹, Ayberk Bostan Sarığlan ${ }^{1}$ \\ ${ }^{1}$ Mathematics and Science Education Department, Necatibey Education Faculty, Balıkesir University, Turkey \\ *Corresponding Author handanurek@,balikesir.edu.tr
}

\begin{abstract}
The present study aims to investigate university students' conceptions of liquids with the help of the scientific story writing technique, which is one of the alternative assessment techniques. The study group comprised students studying science $(n=50)$ and biology teaching departments $(n=20)$ in Turkey. Thus, the study carries within two groups. In both groups, computersupported teaching was carried out by the same researcher for two weeks regarding the subject of liquids. After this process, a scientific story writing technique applies to collect study data. In data analysis, utilized content analysis and descriptive statistics. Firstly, determined the statements involved in students' stories. Afterward, ordered the statements under the categories 'scientifically acceptable', 'partially acceptable,' 'scientifically unacceptable,' and 'not coded.' The findings showed that the category with the highest percentage in the stories of both groups was the scientifically acceptable category. This result indicated that most of the students figured out the subject. However, I encountered several misconceptions also in students' statements. Therefore, enrichment of learning methods is needed to eliminate student misunderstandings detected in learning.
\end{abstract}

Keywords Alternative assessment, Liquids, Scientific story writing, University students.

\section{INTRODUCTION}

Alternative assessment techniques constitute an essential place in student-centered teaching approaches. Alternative assessment techniques focus on the process, not on the result. Various methods used in this respect can be listed as a structured grid, semantic feature analyses, concept map, and concept web (Çepni \& Ayvac1, 2016). Those techniques were determined to positively affect students' science achievement and attitudes (Kirlkkaya \& Vurkaya, 2011). Also, teachers were positive attitudes towards those techniques (Demirelli, Canbazoğlu, Kavak \& Bekçi, 2010). Besides, teachers determined to think that such practices had positive effects on students' motivation, self-esteem, and retention of their knowledge (Güness, Dilek, Hoplan, Çelikoğlu \& Demir, 2010). Moreover, the results of a meta-analysis study indicated that alternative assessment techniques revealed students' academic achievement more effectively when compared to the traditional methods (Gozuyesil \& Tanriseven, 2017).

One of the fundamental reasons for using alternative assessment techniques in science education is to control students' conceptual understandings. Students construct new concepts and reorganize their ideas in the light of their present opinions and beliefs as they learn new knowledge
(Canpolat, Pınarbaşı \& Sözbilir, 2006). In this process, students' pre-knowledge plays an important role. Besides, teachers and the activities presented to the students are also very significant. However, problems faced in the learning process might result in the formation of scientifically unacceptable ideas in the students instead of scientifically acceptable ideas. Resistant ideas of students which contradict scientific knowledge are expressed with different terms such as pre-conceptions, misconceptions, alternative frameworks, naïve conceptions (Coştu \& Ayas, 2005). In this study, such opinions of students are indicated as 'misconceptions' as in various previous research (Coştu \& Ayas, 2005; Dolu \& Ürek, 2015; Eaton, Anderson \& Smith, 1984).

The concept of liquid might assert to be one of the fundamental concepts in science because it can be associated with the primary fields of science. For example, solubility and vapor pressure can assert the concepts related to the idea of liquid in terms of chemistry. Also, it can mention the adhesion and cohesion of water among the associated images in terms of biology. Similarly, it can

\footnotetext{
Received: 28 March 2021

Revised: 1 October 2021

Published: 1 March 2022
} 
indicate buoyancy force in terms of physics. Moreover, the concepts of vaporization and boiling related to the idea of liquid are introduced to the students in physics and chemistry courses in terms of states of matter.

Furthermore, it knows that the concepts of viscosity and surface tension are associated with physics, chemistry, and biology. Therefore, building a correct understanding of liquid makes it significant for university students. However, it should be noted that different definitions of the same phenomena caused in other courses might lead to learning difficulties and misconceptions in students (Nakleh, 1992). Accordingly, it is believed that meaningful learning is required for the students regarding this concept which is typical for separate branches.

The literature reveals that various grade-level students have learning difficulties and misconceptions concerning the concepts on liquid such as vapor pressure and vaporization (Canpolat, Pınarbaşı \& Sözbilir, 2006; Coştu \& Ayas, 2005; Gopal, Kleinsmidt, Case \& Musonge, 2004); liquid state (Leite, Mendoza \& Borsese, 2007); boiling point elevation (Pınarbaşı, Sözbilir \& Canpolat, 2009); solutions, solubility (Kalın 2008; Kalın \& Arık1, 2010; Maass \& Krause, 2014) and change of solid-liquid state of water (A ğgül Yalcin, 2012). Similarly, science teachers teaching in Italy, Portugal, and Spain were also reported to experience conceptual difficulties in this respect (Leite, Mendoza \& Borsese, 2007).

Students develop explanations about the liquid state of matter (liquids) and concepts about the liquid form (for example, solubility) from their early ages as a result of their experiences with issues in a liquid state (Leite, Mendoza \& Borsese, 2007). However, their explanations might not be correct at all. In their study conducted on solutions, Ebenezer \& Erickson (1996) state the following points which affect the conceptions of the students: (i) daily life knowledge of the students (ii) the difficulty in the transition from macroscopic level to a microscopic level (iii) students' failure to understand the technical language which the teachers used. Also, the researchers add that those points influence students' cognitive structures, and they are the causes of misconceptions.

It can assert that students' cognitive structures and language use abilities are closely associated. From those abilities, writing activity influenced the scientists in the fields of linguistics, psychology, and literature (Günel, Kabataş Memiş \& Büyükkasap, 2009). This activity is a complicated process that requires the application of various cognitive procedures (Günel, 2009). The involvement of reading, writing, and speaking elements of language in the science learning process by blending it with inquiry strategies called as 'The Science Writing Heuristic' (Günel, Kabataş Memiş \& Büyükkasap, 2010).

Writing activity is utilized in several forms in science education. An example of this situation is the preparation of experiment reports by the students after laboratory practice. Besides, it might be possible to investigate students' opinions concerning a science concept by getting their written explanations. Moreover, the students can ask to explain views about an education program conducted with a definite method. Such studies are encountered in the literature (Dolu \& Ürek, 2015).

Recently, it has been seen that stories are popular in science education regarding the writing activity utilized in the learning-teaching process. In this respect, scientific reports, which are different types of stories that are very suitable for education, teaching, and communication purposes, are used (Gölcük, 2017). Polat \& Taşar (2013) stated that they could present scientific stories as course material to conduct effective learning or utilize as an alternative assessment instrument. Although scientific story writing is not a widely used assessment technique in science education (Rose, 2017), they are found instructive and entertaining by the teacher candidates (Anilan, 2018).

In the research, it is seen that scientific stories were developed by the researchers on definite science concepts (Demircioğlu, Ayas, Demircioğlu \& Özmen, 2015; Erten, Kıray \& Şen-Gümüş, 2013; Polat \& Taşar, 2013) or they were presented to the students by taking them from various sources (Demircioğlu, Ayas, Demircioğlu \& Özmen, 2015; Tao, 2002). Thus, it states that scientific concepts and events could make more accessible to understand (Erten, Kıray \& Şen-Gümüş, 2013). Also, scientific stories have utilized the students to determine their comprehension and opinions about a subject (Bostan Sarığlan, 2014).

When the studies conducted by using scientific stories investigate, it is seen that several studies focus on the nature of science. In one of those studies, Tao (2002) conducted instruction for high school level students to develop their understanding of the nature of science. The researcher analyzed the focal awareness of the students while they were examining four scientific stories given to them. As a result of the study, the students focused on the stories by considering only one or two aspects of science. Also, Polat \& Taşar (2013) conducted research on science teaching students' opinions about the nature of science. The researchers utilized eight short stories and concluded the efficacy of those stories due to their study. Finally, in another study, Erten, Kiray \& Şen-Gümüş, (2013) investigated the effect of scientific reports on the fifth and sixth-grade level students' opinions related to science and scientists. Their study demonstrated changes in students' stereotypical ideas on laboratory equipment, technological devices, and the environment where scientists conducted their investigations.

Some studies address various science concepts by utilizing scientific stories. In one of such studies, Dimitriadi, Halkia, \& Skordoulis (2009) conducted qualitative research to teach Special Relativity Theory to high school students more effectively. This study presented scientific stories to the students in the form of worksheets. 
The students who worked in groups were asked to discuss the stories and answer the questions related to the levels. The results indicated that students got the basic ideas of the theory despite its difficulty. Also, Bostan Sarıoğlan (2014) examined science teacher candidates' metacognitive and scientific story writing skills. The researcher asked the participants to construct a scientific story about the concept of heat that could be used in the introduction part of a science course. The teacher candidates' reports were analyzed according to a rubric that involved several criteria: purpose, cognitive level, fluency, planning, and hypothesis construction. The results revealed that the stories did not reflect the requirements sufficiently. Besides, Demircioğlu, Ayas, Demircioğlu \& Özmen (2015) utilized scientific reports to investigate science teacher candidates' comprehension of the states of matter. The researchers used scientific stories in the form of instructional materials and examined their effect on teacher candidates' achievements and attitudes towards chemistry. The results showed positive effects on teacher candidates' accomplishments and perspectives.

As can be seen, the abovementioned research generally considers the utilization of scientific stories presented to the students on a definite science subject. However, limited research deals with the scientific stories about a science concept created by themselves. In the present study, the stories written by Turkish university students are considered. Those are the students who enter education faculty with a central university entrance examination conducted in three sessions. This examination consists of multiple-choice questions which reflect the traditional assessment approach. Turkish Assessment, Election, and Placement Center inform that a total of 2.416.974 students took the introductory sufficiencies session of this exam in 2021 (AEPC, 2021). Unfortunately, a recent study reports that Turkish students mostly perceive this exam as a horse race, death, torture, nightmare, and nonsense (Baş \& Kıvilcım, 2019). Besides, despite highlighting active learning approaches in the chemistry and science teaching programs (MoNE, 2018a; 2018b), it is realized that there are problems in conducting student-centered instruction in Turkey (Özpolat, 2013). So, it can conclude that Turkish students experience several challenges when studying university courses and introductory chemistry.

According to the research, another problematic issue is that laboratory applications are not achieved sufficiently at schools in Turkey (Bat1, 2018). However, chemistry is a practical subject (Taber, 2019). Students work in groups with peers and develop various science process skills during laboratory applications. Also, it is shown that students in all grades possess conceptual problems related to chemical concepts (Tsaparlis, 2016). A variety of methods and techniques are utilized in this respect. Upon those issues, it is expected that using an alternative assessment technique will allow the researchers to examine students' conceptions by involving their active participation, cooperation with peers, and creativity.

\subsection{The Aim and Significance of the Study}

This study aims to examine Science and Biology Teaching Students' conceptions of liquids with the help of the scientific story writing technique, which is one of the alternative assessment techniques. In addition, it intended to compare two groups in terms of their conceptions. Thus, it will be possible to determine how students' conceptions reflected on their stories in terms of scientific perspective.

Alternative assessment techniques are more advantageous in involving students in the learning-teaching process and motivating them than traditional approaches (Güneş, Dilek, Hoplan, Çelikoğlu \& Demir, 2010). However, it might assert that alternative assessment techniques are less common than traditional ones. Thus, higher education students' assessments are based on paperpencil tests, and they are evaluated with the help of the grades they take from those tests (Frank \& Barzilai, 2004). For those reasons, this study addresses an alternative assessment technique.

The research questions are as follows:

1. What are the conceptions of Science Teaching Students (STS) about the subject of liquids in the scientific stories they wrote?

2. What are the conceptions of Biology Teaching Students (BTS) about the subject of liquids in the scientific stories they wrote?

\section{METHOD}

\subsection{Study Design}

This study was conducted in an embedded single-case design, one of the case study models of the qualitative research approach. This model used in the studies which involve several sub-layers in a single case and accordingly which have several analysis units (Yıldırım \& Şimşek, 2016). The issue addressed in this study was university students' conceptions about the subject of liquids. The study sample involved two groups of majors, namely STS and BTS. Thus, the study aimed to determine students' conceptions in two sub-layers in detail.

\subsection{Participants}

The study participants comprised STS $(\mathrm{n}=50)$ and BTS $(n=20)$ studying in the education faculty of a governmental university located in the west part of Turkey. All the participants were year one students taking the Chemistry I coursed when the study was conducted. The study sample was formed via the purposive sampling method, one of the non-random sampling methods. In this method, information-rich situations are selected in the context of the purpose of the study to conduct in-depth research (Büyüköztürk, Kılıç-Çakmak, Akgün, Karadeniz \& Demirel, 2018). In the present study, the academic achievements of the participants take into consideration to 
form the study sample. First, the participants were listed according to the grades they took from the midterm examination of the Chemistry I course. Afterward, the students in both science and biology teaching departments were divided into groups of five which involved different achievement levels. This procedure resulted in ten groups of STS and four groups of BTS.

The reason involvement of two different groups in the study was due to the characteristics of the selected subject. The subject, liquids, is common for both science and biology teaching students. Water is an essential liquid in the world, and its properties are studied in all branches of science, namely in physics (for example, liquid pressure), chemistry (for example, states of matter), and biology (for example, capillarity). Also, the subject of liquids was addressed in terms of an introductory chemistry course at both groups. Hence, it was aimed to determine and compare students' opinions impact of their majors on their conceptions in the study.

\subsection{Data Collection Instrument}

Scientific stories which the students wrote constituted data collection instruments of the study. Before writing the stories, both groups of students were taught the subject of liquids in their Chemistry I course with the help of computer-supported teaching for four hours a week by the same researcher. The teaching period lasted for two weeks. In the teaching period, several animations that demonstrated daily life applications of liquids were presented to the students. The spirits also involved microlevel demonstrations of the concepts. Thus, it is intended to make students' understanding easier and stable. Besides, the teaching process was supported by laboratory practice which lasted for four hours. In this practice, various experiments were performed by the students under the guidance of two teaching assistants. Students ' experiments dealt with the concepts of surface tension, adhesioncohesion, viscosity, boiling-evaporation, and freezingmelting.

\subsection{Treatment}

The data collection part of the study was conducted in the science laboratory. After working on the teaching process, the students were asked to write their scientific stories to reveal their conceptions about liquids. The students were given one hour to complete their stories. Firstly, the students were provided with knowledge that explained the purpose and details of the study. In this respect, the following guidelines were stated: (i) brainstorming on the subject with their groupmates, (ii) thinking about real-life associations of the concepts, (ii) cooperating with their peers (iv) constructing an excellent scientific story. Thus, it was highlighted that they could form a story with integrity by moving from their ideas. Also, it was added that they could write another story if they wished-afterward, the students were given A3 size sheets to write their scientific stories.
Students' conceptions were not investigated with a pretest application in this study. Making a comparison between students' pre and post-learning was not a target of this study since it did not aim to do experimental research. Instead, the study was based on examining their conceptions related to the subject of liquids after the instruction. As mentioned earlier, the matter was taught to the students by the same instructor and teaching assistance using the same methods. As a result of the writing activity, ten scientific stories were collected from STS, whereas four were obtained from BTS.

\subsection{Data Analysis}

Content analysis was utilized in the study of the stories. In this process, collected data is firstly conceptualized, then it is organized logically according to the concepts emerged and accordingly, themes which explain data are determined (Yıldırım \& Şimşek, 2016).

Two researchers read the stories and determined the statements about liquids in the analysis process. A total of 22 statements determine in the stories of STS, and 12 comments determine in the stories of BTS. STS' reports were coded with $S S$, and BTS' statements were coded with $B S$. For example, SS7 was used to indicate the seventh statement in the stories written by STS. After the coding, the students' words were placed in the categories determined during the analysis process.

A total of four categories were identified due to the analysis of the stories. Those categories are taken from the previous literature (Coştu, Karataş \& Ayas, 2003; Gabel, Stockton, Monaghan \& MaKinster, 2001; Kocakülah, 1999). the opinions of two chemistry education and one science education expert were asked related to the statements and categories to obtain content validity. The views were placed under proper categories independently by two researchers. The interrater consistency was checked during students' opinions under appropriate categories, and the consistency coefficient was calculated to be .90 (Miles \& Huberman, 1994). This value indicated the reliability of data analysis since it exceeds .70 (Yildırım \& Şimşek, 2016). Two researchers firstly discussed several points on which they had disagreements to solve them. However, when the clashes continued, they referred to the third researcher's opinion to resolve them. Thus, the placement of all statements under proper categories was achieved. Besides, two researchers reanalyzed a selected part of the data source one week later. Therefore, it assured the reliability of the data analysis. The categories used in data analysis are explained below:

Scientifically Acceptable Responses: In this category, the students' responses matched with scientific facts, and they explained the reasons for their responses correctly. Those responses did not involve an incorrect statement (Gabel, Stockton, Monaghan \& MaKinster, 2001; Kocakülah, 1999). 
Partially Acceptable Responses: In this category, the students' statements about the subject of liquids matched with scientific facts. However, the reasons for their responses were not explained correctly (Coştu, Karataş \& Ayas, 2003; Gabel, Stockton, Monaghan \& MaKinster, 2001).

Scientifically Unacceptable Responses: The students' statements in this category did not match scientific facts. Misconceptions concerning the subject of liquids were involved in this category (Kocakülah, 1999).

Not Coded Responses: The students' statements that were not associated with the subject of liquids were included in this category (Gabel, Stockton, Monaghan \& MaKinster, 2001; Kocakülah, 1999).

Finally, the statements determined in each category were tabulated with descriptive statistics methods.

\section{RESULT AND DISCUSSION}

This section presents the findings obtained from the analysis of scientific stories about liquids that the students wrote after the instruction of the issue.

The frequency and percentage distribution of the findings, which were shown in Table 1 , are presented in Table 2. According to Table 2, 22 statements were determined in the stories written by STS, whereas 12 reports were obtained from BTS. $68 \%$ of STS' comments were scientifically acceptable, whereas $58 \%$ of BTS' statements matched with scientific responses. In addition, 9\% of STS' reports were partially good, and they indicated a correct understanding of the students with incorrect explanations. However, no such statements were encountered in BTS' stories. On the other hand, $18 \%$ of STS' statements and $34 \%$ of BTS' views were scientifically unacceptable. Besides, several misconceptions were encountered among such statements of both group students. Also, $5 \%$ of STS' views and $8 \%$ of BTS's words were not coded.
Table 1 The analysis results of the scientific stories written by the students

\begin{tabular}{|c|c|c|}
\hline Categories & STS & BTS \\
\hline Scientifically Acceptable & $\begin{array}{lr}\text { SS1, } & \text { SS2, } \\
\text { SS3, } & \text { SS6, } \\
\text { SS7, } & \text { SS8, } \\
\text { SS9, } & \text { SS11, } \\
\text { SS12, } & \text { SS14, } \\
\text { SS16, } & \text { SS17, } \\
\text { SS19, } & \text { SS20, } \\
\text { SS21 } & \end{array}$ & $\begin{array}{ll}\text { BS1, } & \text { BS2, } \\
\text { BS4, } & \text { BS5, } \\
\text { BS7, } & \text { BS8, } \\
\text { BS9 } & \end{array}$ \\
\hline Partially Acceptable & SS10, SS13 & - \\
\hline $\begin{array}{l}\text { Scientifically } \\
\text { Unacceptable }\end{array}$ & $\begin{array}{l}\text { SS4, SS5, } \\
\text { SS15, SS18 }\end{array}$ & $\begin{array}{l}\text { BS3, BS6, } \\
\text { BS10, BS12 }\end{array}$ \\
\hline Not Coded & SS22 & BS11 \\
\hline
\end{tabular}

Table 2 The frequency and percentage distribution of the statements in scientific stories with respect to the categories

\begin{tabular}{lllll}
\hline \multirow{2}{*}{ Categories } & \multicolumn{2}{c}{ STS } & \multicolumn{3}{c}{ BTS } \\
\cline { 2 - 5 } & f & $\mathbf{\%}$ & f & \% \\
\hline Scientifically Acceptable & 15 & 68.0 & 7 & 58.0 \\
Partially Acceptable & 2 & 9.0 & - & - \\
Scientifically Unacceptable & 4 & 18.0 & 4 & 34.0 \\
Not Coded & 1 & 5.0 & 1 & 8.0 \\
\hline Total & 22 & 100.0 & 12 & 100.0 \\
\hline
\end{tabular}

The analysis results also showed that the students' stories did not include all the categories simultaneously. So, several examples from the stories are shown in Figures 1, 2 , and 3 , with the coding of the statements in different types as follows.

Figure 1 shows a story with six statements written by STS. Five of those statements were scientifically acceptable (SS7, SS8, SS9, SS11, SS12), whereas one of them was partially satisfactory (SS10).

Figure 2 demonstrates a story that includes three statements written by STS. One of those statements was

\begin{abstract}
Ayşe felt hungry and went to the kitchen to help her mother who was cooking. She asked her mother to cook pasta. Her mother stated that it was simple, and Ayşe could also cook it. Afterwards, her mother explained Ayşe how to cook pasta. Ayşe took a pot of water and placed it on the stove. When the water

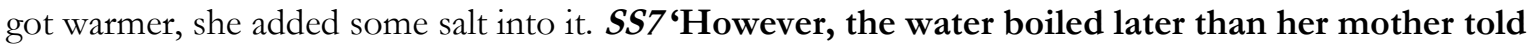
her.' Thus, Ayşe wondered the reason of this situation and began to investigate it. She asked her science teacher about it and her teacher explained her. $\boldsymbol{S S \boldsymbol { S }}$ 'The factor which was affective on boiling was the equivalence of inner pressure of the water to the outer pressure.' SS9 'However you changed the inner pressure since you added salt into it and that caused a longer time than you expected for the water to boil.' The teacher added those sentences as well: $\boldsymbol{S S 1 0}$ 'The liquids make vibrational and translational motion, so they are fluids.' $S S 11$ 'Evaporation can happen in each temperature but boiling cannot.' SS12 'The distinct feature of water which makes it different than the other types of liquids is the fact that its volume increases while it freezes.'
\end{abstract}

Figure 1 An example from sts' scientific stories which includes scientifically acceptable and partially acceptable statements 
Ecrin woke up on a sunny morning. She realized that she had to save the day for herself as she saw sun rays coming into her room. She left the house with her toys after eating her breakfast. Then, she called her mother and asked for a glass of cold water because she got very hot outside. Her mother left a glass of icy water beside her. She did not drink it immediately. SS4 'She approached to the glass after a while, and she noticed that the ice disappeared.' Then, she realized that it was not cold anymore after taking a sip of water from the glass. Soon, she ran to her mother and asked the reason of this situation. SS5 'Her mother said that the temperature caused the ice to melt and so, ice changed into water.' SS6 'And she added that liquids vaporized at all temperatures.' Finally, Ecrin became so happy to find answers to her questions.

Figure 2 An example from sts' scientific stories which includes scientifically acceptable and scientifically unacceptable statements

There were two ducks called Azman and Sarman who were living in two different ponds. One of the ponds was dirty because of the chemical wastes. On the other hand, the other one was clean. One day, they met and began to talk to each other. Sarman who lived in the dirty pond explained his friend, Azman that he experienced problems while swimming in the pond each time. BS11 'Sarman added that it was hard to swim in a pond with chemical wastes due to the low surface tension because of the chemicals.' BS12 'However, Azman knew that there was a relationship between swimming and density of the pond with chemical wastes since he swam in salty water more easily.' So, Sarman decided to make an experiment for his friend. Two friends firstly swam in the clean pond. In this clean, fresh pond, Sarman realized that he moved comfortably. Afterwards, they went to the dirty pond with chemicals. Azman had difficulties in swimming and finally he got stuck there. Sarman left him in the dirty pond and went to live in the clean pond.

Figure 3 An example from bts' scientific stories, which includes scientifically unacceptable and not coded statements

scientifically acceptable (SS6), whereas two were scientifically unacceptable (SS4 and SS5).

Figure 3 shows one of the scientific stories BTS wrote and determined to have two statements. One of the statements was in the category of scientifically unacceptable (BS12), whereas the other one was in the category of not coded (BS11).

As a result of the study, the findings obtained from the analysis of the stories revealed that $68 \%$ of STS' statements and $58 \%$ of BTS's statements were scientifically acceptable. This result indicated that students mostly understood the concepts concerning liquids after the teaching process. Besides, 9\% of STS' statements were partially acceptable. On the other hand, no partially acceptable statements were determined in BTS' stories. As mentioned previously, students' incorrect explanations caused their responses to occur under this category despite their correct opinions.

Moreover, $18 \%$ of STS' statements were scientifically unacceptable, whereas $5 \%$ were not coded. Also, 34\% of BTS' statements were scientifically unacceptable, whereas $8 \%$ were not coded. Although the study groups involved different students, the analysis results considered the percentages of the statements at both science and biology teaching groups. Those values were calculated by taking the ratio of relative students to the whole group. Hence, the percentages were accepted as a basis for making comparisons in the study. Thus, it might be stated that STS was more successful than BTS since STS constructed relationships among the concepts better, as can be understood from the higher percentage of scientifically acceptable statements and lower percentages of scientifically unacceptable and not coded messages.

As mentioned above, most of the students' statements were determined to belong to the category of scientifically accepted. In BS1, students stated, "the liquid began to take the form of the pot while it was being poured into it." As it is known, the liquids are fluid, and they take the form of the container in which they are put (Mortimer, 1997). In SS3, students indicate, "I have viscosity, adhesion, and surface tension." In this statement, they highlight three properties related to the liquids. Various studies address those concepts in the literature (Mortimer, 1997; Ok, 2019; Özdemir, Merve, Ok \& Kabapinar, 2021; Petrucci, Herring, Madura \& Bissonnette, 2012). In SS12, it is stated that "the distinct feature of water which makes it different than the other types of liquids is the fact that its volume increases while it freezes." Here, the students started an essential feature of water correctly. The volume of any liquid decreases while freezing. However, the importance of water increases while freezing. The reason for this situation is explained with the help of hydrogen bonds. The hydrogen bonds in the crystal structure of ice are arranged in a hexagonal form, whereas 
the hydrogen bodies in water are packed more tightly. This situation causes the form of water to occupy a smaller volume when compared to the state of ice (Chang \& Goldsby, 2018; Dolu, 2017; Petrucci, Herring, Madura \& Bissonnette, 2012).

In SS14, "adhesion is the interaction between two different substances, for example, the interaction between water and leaf, whereas cohesion is the interaction in the same substance, for example, the interaction among water molecules, and thus, Ayse gained various information about the things; she encountered in daily life." In this statement, students made correct definitions for adhesion and cohesion. Cohesion is the force of attraction between liquid molecules, whereas adhesion is the force between the liquid molecules and the surface they are in contact with (Sar1kaya, 2011). SS16 was written as "the resistance of the liquids to flow is called as viscosity and every liquid has a different viscosity." In this statement, students defined the concept of viscosity correctly. This definition is encountered in various sources (Mortimer, 1997; Ok, 2019; Petrucci Petrucci, Herring, Madura \& Bissonnette, 2012). In another study, Özdemir, Merve, Ok \& Kabapinar (2021) explain that water and glycerine have different viscosities due to the number of hydrogen bonds. The researchers indicate that glycerine has a higher viscosity than water because glycerine has more hydrogen bonds when compared to water.

SS20 was in the form of "I asked my teacher: Why does the giant ship float on water but a piece of stone sinks? My teacher explained this situation with the help of buoyancy and added that the density of water is enough to lift the ship, but it makes the stone sink." In this statement, the students mentioned the concepts of buoyancy and density. The buoyancy force equals the weight of an object that floats or hangs on (Şahin, 2013). Besides, density is the mass of a substance per unit volume (Mortimer, 1997). Therefore, the implications of a density lower than water do not sink in water.

On the other hand, the substances with a higher density than water sink in water. The literature also indicates ships floating on water and stones sinking in a river. This situation is encountered in daily life (Karaçam \& Gürsel, 2017), similar to the present study results.

When the students' statements were investigated, there were two partially acceptable responses in the stories written by STS. SS10 was written in the form of "liquids make a vibrational and translational motion, so they are fluids." The fact that liquid molecules make a vibrational and translational motion is correct. However, indicating this movement as the reason for the fluidity of the liquids is not a proper explanation. So, this statement was evaluated under the category of partially acceptable. In SS13, "surface tension is the energy required to increase the surface for $1 \mathrm{~cm}$. Later, she realized that the leaf was floating on water not just because of surface tension only. Still, this situation was also related to adhesion and cohesion.", the students defined surface tension correctly. However, they failed to explain that the leaf was floating on water due to density differences. Instead, they mentioned surface tension, adhesion, and cohesion in this respect. Similarly, Thompson \& Logue (2006) determined that different ages students did not use the concept of surface tension correctly due to their study, which investigated the floating or sinking of other objects in the water.

When the statements which took place under the category of scientifically unacceptable were analyzed, SS4 was found as "she approached the glass after a while, and she realized that the ice disappeared." This statement indicated a misconception. In here, Ecrin should state that ice had melted. However, she noted that the ice had disappeared. This response cannot be accepted as a scientific notion. It might be specified that this misconception stems from the use of daily life language in the explanation of a scientific situation (Leach \& Scott, 2002; Yağbasan \& Gülçiçek, 2003).

Moreover, SS5 stated that "her mum said that the temperature caused the ice to melt, so ice changed into the water," which was also a common misconception in the literature. In this statement, the notion of temperature instead of heat to melt ice was not scientific. The research indicates that students have confusion about the concepts of heat and temperature, and they can use them interchangeably (Aydoğan, Güneş \& Gülçiçek, 2003; Jara-Guerrero, 1993; Thomaz, Malaquias, Valente \& Antunes, 1995).

In SS15, "Ali who grabbed a plastic bottle began to fill the bottle with water in the tap; how could the bottle be filled if there were no liquids? or how could be empty the full bottle?", students were seen to have a confusion on the concepts of fluidity and transmission. The students were determined to think of water like mud or fine sand in their statement. Thus, they made an overgeneralization mistake and possessed a misconception in this respect (Ayas, 2016; Coştu, Ayas \& Ünal, 2007). Also, in SS18, students stated that a "rise in pressure causes a decrease in viscosity." Thus, the students thought that the increase in pressure decreases viscosity. However, a rise in pressure causes a replacement in the number of spaces among the molecules. Thus, the movement of the molecules becomes difficult, and the viscosity increases (Bayram, 2018). Hence, this statement was evaluated under the category of scientifically incorrect.

In BS3, it was stated that "liquids cannot be compressed completely." Here, it is seen that BTS possesses the misconception that liquids could be compressed at a definite amount. However, the volume of liquids does not change in a measurable amount when the pressure applied to the liquid increases. Thus, the opinion that fluids can be compressed at a definite amount does not match the scientific point of view. A similar finding was also encountered in the study of Kirtak Ad \& Kocakülah (2017), which was conducted with science teacher candidates. Besides, the students were determined to think that sugar water (solution) does not boil without becoming 
supersaturated based on their statement, BS6, "sugar water boils in supersaturated state at high temperature." However, the concepts of boiling and supersaturation are distinct from each other. The literature reports such misconceptions as well (Kalın, 2008; Kalın \& Arıkı1, 2010; Pınarbaş1, Sözbilir \& Canpolat, 2009).

In BS10, "when the order of viscosities is considered, the viscosity of liquid detergent is higher than the viscosity of glycerine," a misconception is detected. Viscosity is the resistance of the liquids towards flowing, and the viscosity of glycerine is known to be higher than the liquid detergent. However, the students were determined to possess a misconception in this respect. In her study, Kirtak Ad (2016) reported that university students held scientifically unacceptable notions by explaining the concept of viscosity with density and structure of matter (for example, honey contains sugar). Also, in BS12, "However, Azman knew that there was a relationship between swimming and density of the pond with chemical wastes since he swam in salty water more easily.", the students associated the concept of density with swimming activity. However, it is not scientific to explain swimming with density directly here. The buoyancy force is significant in the case of swimming. Also, saltwater is a solution (homogeneous mixture) and has more density than pure water. However, water with chemical wastes is a heterogeneous mixture. It might have more density than pure water, but it is not easy to swim in it. So, the statement does not match with scientific opinions.

The study results also revealed several statements that were collected under the category of not coded. For example, in SS22, students stated, "contents of the opened barrel were poured into the sea, and I saw that the spilled was not submerged in the water." This statement was the final statement of the story, which a group wrote of STS. It was not associated with the whole account, and an explanation did not follow it. Thus, it was analyzed as not coded. In addition, BS11, "Sarman added that it was hard to swim in a pond with chemical wastes due to the low surface tension because of the chemicals," revealed confusion in students' opinions. Namely, it is seen that the students tried to connect the concept of surface tension with swimming activity. Therefore, no appropriate association between swimming activity and the idea of surface tension might be indicated as the reason for the evaluation of this statement under the category of not coded.

The analysis results showed that students primarily structured their stories around the concepts of viscosity, adhesion, cohesion, and surface tension. On the other hand, it is remarkable that the research which examines students' conceptions on those concepts is very limited in the literature (Kırtak Ad, 2016; Kırtak Ad \& Kocakülah, 2017). However, the stories were also detected to involve the concepts of evaporation and solutions. Those concepts are seen to be addressed in the literature more often (Canpolat, Pınarbaşı \& Sözbilir, 2006; Coştu \& Ayas, 2005;
Gopal, Kleinsmidt, Case \& Musonge, 2004; Kalın 2008; Kalın \& Arık1l, 2010; Maass \& Krause, 2014).

When the present study is considered in terms of the teaching method of computer-supported teaching, it is seen that the contents of animations which showed daily life practice (for example, some amount of water boiling in a pot, the resistivity of honey towards flowing) were reflected in the stories written by the students. This situation is related to the nature of the stories because they are based on experiences (Gölcük, 2017). Work done in the kitchen and water pollution can be listed among such impacts in students' scientific stories. However, it was seen that the students avoided micro-level explanations in their stories even though such demonstrations were also shown to them in the courses. Although the students talked about a glass or bottle of water, no one gave place to its molecules in their stories. This situation matches the finding that the students generally experience difficulties while passing from macro to micro-level (Ebenezer \& Erickson, 1996).

As mentioned earlier, the present study focused on determining students' conceptions after the teaching process. Hence, the target of the investigation was not to make a comparison between students' pre and post conceptions in the groups. On the contrary, the impacts of teaching and utilization of such an alternative assessment technique were considered. It was clear that both group students encountered the Chemistry I course for the first time in their university education period since they were all first-year students. Hence, it was expected that the study contributed to students' conceptions about liquids and improved their abilities such as cooperation with their peers, creativity, task completion, as can be understood from the high percentages of scientifically acceptable statements. The concepts such as the distinct feature in the freezing of water, surface tension, adhesion, and cohesion are not highlighted during science teaching programs in the middle school (MEB, 2018a) and high school chemistry program (MEB, 2018b). However, the stories written by the students demonstrated that they could structure those concepts.

The advantages and disadvantages of the utilization of scientific story writing techniques to figure out the mental structures of students can be considered as another subject to be discussed. Determination of misconceptions of the students and identifying the type of associations (correct or incorrect associations) among the concepts might be stated in terms of the advantages of this technique (Demircioğlu, Demircioğlu \& Ayas, 2006). Also, revealing the real-life applications of those concepts from students' perspectives is another positive aspect of the technique. Thus, it is thought that the scientific stories created by the students can give an idea to the researchers about the extent to which the subject is understood. Several studies in this respect concluded the rise in students' academic achievement and elimination of their misconceptions 
(Demircioğlu, Ayas, Demircioğlu \& Özmen, 2015). In addition, the utilization of scientific stories was reported to trigger interest and curiosity in students (Gölcük, 2017).

As well as its advantages, the utilization of scientific stories to find out the students' conceptual understandings might be asserted to include several disadvantages. The insufficiencies of the students in grammar constitute a significant problem in this respect. The lack of harmony among the students in groups is another negative feature that influences the quality of the stories written by the students. In her study, Bostan Sarıoglan (2014) expressed that scientific stories written by science teacher candidates were not successful enough in terms of involving the criteria such as planning, hypothesis construction, application, and summarization.

In light of the study findings, it can be indicated that the researchers can consider several points to obtain effective results from the utilization of this technique. Firstly, a detailed preparation step is necessary before applying this technique to students. Furthermore, the researchers' knowledge, skill, and attitudes towards alternative assessment techniques is another essential point for the application to achieve its purpose (Yurdabakan, 2011). Additionally, it is required to conduct effective time management and classroom coordination during the application process (Güneş, Dilek, Hoplan, Çelikoğlu \& Demir, 2010). Finally, the coding and analysis of the stories which were obtained as a result of the application process might create a challenging step for the researchers (Yildirım \& Şimşek, 2016).

\section{CONCLUSION}

The present study considered the conceptions of STS and BTS concerning the subject of liquids with the help of scientific stories which were written by them. The analysis results indicated that students' conceptions mostly gathered under the category of scientifically acceptable. Besides, it was seen that they possessed several conceptions which needed to be improved. This finding implied that the teaching methods used in this study should be enriched to improve their partially acceptable concepts and eliminate misconceptions as well. Also, it was seen that the conceptions of STS were better than those of BTS.

It might be asserted that this alternative assessment technique gave more detailed information about students' ideas when compared to the traditional assessments. The purpose of such alternative measurements is that they give clues about the causes of the problem related to the conceptions of the students rather than what is wrong or what is right.

It is thought that future studies might deal with different subjects by using the same technique. Also, students' conceptions on viscosity, surface tension, adhesion, and cohesion might be explicitly considered. In addition, it is expected that the same technique might be applied to younger students effectively

\section{REFERENCES}

Assessment, Election and Placement Center (AEPC). (2021). YKS Numerical data. https://dokuman.osym.gov.tr/pdfdokuman/2021/YKS/sayisal veriler 28072021.pdf.

Ağgül Yalcin, F. (2012). Pre-service primary science teachers' understandings of the effect of temperature and pressure on solidliquid phase transition of water. Chemistry Education Research and Practice, 13, 369-377.

Anilan, B. (2018). Views and experiences of pre-service teachers on the use of stories in teaching science. Journal of Baltic Science Education, 17(4), 605-619.

Ayas, A. (2016). Kavram öğrenimi [Concept learning]. In S. Çepni (Ed.), Kuramdan Uygulamaya Fen ve Teknoloji Ögretimi [Science and Technology Teaching from Theory to Practice] (pp. 191-220), Ankara: Pegem Akademi.

Aydoğan, S., Güneş, B. \& Gülçiçek, Ç. (2003). Isı ve sıcaklık konusunda kavram yanilgilar1 [The misconceptions about heat and temperature]. Gaæi Ë̆itim Fakültesi Dergisi [Gazi University Journal of Gazi Education Faculty], 23(2), 111-124.

Baş, G., \& Kıvılcım, Z. S. (2019). Türkiye'de öğrencilerin merkezi sistem sınavları ile ilgili algıları: bir metafor analizi çalışması [Perceptions of students on central system examinations in Turkey: a metaphor analysis study]. Eğitimde Nitel Arastermalar Dergisi - Journal of Qualitative Research in Education, 7(2), 639-667.

Batt, K. (2018). A literature review of laboratuary studies in science and chemistry education in Turkey. Doğu Anadolu Sosyal Bilimlerde Eğilimler Dergisi [Journal of Eastern Anatolia Social Sciences Trends], 2(1), 45-55.

Bayram, H. (2018). Maddenin yoğun halleri: Sivilar ve katılar [Intense states of matter: Liquids and solids]. In H. Bağ \& G. Dolu. (Eds.), Kimya I [Chemistry I] (pp. 235-263), Ankara: Pegem Akademi.

Bostan Sarığlan, A. (2014). Comparison of science teacher candidates' metacognitive and scientific story writing skills. International Journal on New Trends in Education and Their Implications, 5(2), 126- 133.

Kirikkaya, E. B., \& Vurkaya, G. (2011). The Effect of Using Alternative Assessment Activities on Students' Success and Attitudes in Science and Technology Course. Educational Sciences: Theory and Practice, 11(2), 997-1004.

Büyüköztürk, Ş., Kılıç-Çakmak, E., Akgün, Ö. E., Karadeniz, Ş., \& Demirel, F. (2018). Eğitimde bilimsel arastırma yöntemleri [Scientific research methods in education 7 (25 ${ }^{\text {th }}$ Ed.). Ankara: Pegem Akademi.

Canpolat, N., Pınarbaşı, T., \& Sözbilir, M. (2006). Prospective teachers' misconceptions of vaporization and vapor pressure. Journal of Chemical Education, 83(8), 1237-1242.

Chang, R., \& Goldsby, K. A. (2018). Genel kimya [General chemistry]. (R. Inam, \& S. Aksoy, Trans.). (11 $\mathrm{t}^{\mathrm{h}}$ Ed.). Ankara: Palme Yayıncilik.

Coştu, B., Karataş, Ö., \& Ayas, A. (2003). Kavram öğretiminde çalışma yapraklarının kullanilmasi [The use of worksheets in concept teaching]. Pamukkale Üniversitesi Eguitim Fakültesi Dergisi Pamukekale University Journal of Education Faculty], 14(2), 33-48.

Çepni, S., \& Ayvac1, H.Ş. (2016). Fen ve teknoloji eğitiminde alternatif (performans) değerlendirme yaklaşımları [Alternative (performance) assessment techniques in science and technology education]. In S. Çepni (Ed.), Kuramdan Uygulamaya Fen ve Teknoloji Ögretimi [Science and Technology Teaching from Theory to Practice] (ss. 389405), Ankara: Pegem Akademi.

Coștu, B., \& Ayas, A. (2005). Evaporation in different liquids: secondary students' conceptions. Research in Science \& Technological Education, 23(1), 75-97.

Coştu, B., Ayas A., \& Ünal, S. (2007). Kavram yanılgıları ve olası nedenleri: Kaynama kavramı [Misconceptions about boiling and their possible reasons]. Kastamonu Ë̈itim Dergisi [Kastamonu Education Journal], 15(1), 123-136. 
Demircioğlu, H., Ayas, A., Demircioğlu, G., \& Özmen, H. (2015). Effects of storylines embedded within the context-based approach on pre-service primary school teachers' conceptions of matter and its states. Asia-Pacific Forum on Science Learning and Teaching, 16(2), 1 30.

Demircioğlu, H., Demircioğlu, G., \& Ayas, A. (2006). Hikayeler ve kimya ögretimi [Storylines and chemistry teaching]. H.U. Journal of Education, 30, 110-119.

Demirelli, H., Canbazoğlu, S., Kavak, N., \& Bekçi, N. (2010). Science teachers' competencies about alternative assessment methods. In G. Çakmakçı \& M.F. Taşar (Eds.), Contemporary Science Education Research: Learning and Assessment (pp. 369-375), Ankara, Turkey: Pegem Akademi.

Dimitriadi, K., Halkia, K., \& Skordoulis, C. (2009). An attempt to teach the theory of special relativity to students of upper secondary education. In G. Çakmakçı \& M.F. Taşar (Eds.), Contemporary Science Education Research: Learning and Assessment (pp. 183-187), Ankara, Turkey: Pegem Akademi.

Dolu, G. (2017). Kimyasal bağlar [Chemical bonds]. In H. Bağ \& G. Dolu (Eds.), Kimya I Chemistry I] (pp.137-163), Ankara: Pegem Akademi.

Dolu, G. (Ed.). (2018). Kimyada kavram yanlgzlar [Misconceptions in chemistry]. Ankara: Pegem Akademi.

Dolu, G., \& Ürek, H. (2015). Identification and elimination of several misconceptions of university-level students regarding the misconceptions in a science course. Croatian Journal of Education, 17(2), 353-382.

Eaton, J. F., Anderson, C. W., \& Smith, E. L. (1984). Students' misconceptions interfere with science learning: Case studies of fifth-grade students. The Elementary School Journal, 84(4), 365-379.

Ebenezer, J. V., \& Erickson, L. G. (1996). Chemistry students' conception of solubility: a phenomenography. Science Education, 80(2), 181-201.

Erten, S., Kıray, S. A., \& Şen-Gümüş, B. (2013). Influence of scientific stories on student's ideas about science and scientists. International Journal of Education in Mathematics, Science and Technology, 1(2), 122137.

Frank, M., \& Barzilai, A. (2004). Integrating alternative assessment in a project-based learning course for pre-service science and technology teachers. Assessment \& Evaluation in Higher Education, 29(1), 41-61.

Gabel, D. L., Stockton, J. D., Monaghan, D. L., \& MaKinster, J. G. (2001). Changing children's conceptions of burning. School Science and Mathematics, 101(8), 439-451.

Gopal, H., Kleinsmidt, J., Case, J., \& Musonge, P. (2004). An investigation of tertiary students' understanding of evaporation, condensation, and vapour pressure. International Journal of Science Education, 26(13), 1597-1620.

Gozuyesil, E., \& Tanriseven, I. (2017). A Meta-analysis of the effectiveness of alternative assessment techniques. Eurasian Journal of Educational Research, 70, 37-56.

Gölcük, A. (2017). Bilimsel bikâyelerle desteklenen fen eğitiminin öğrencilerin yaratcollklar ve duyussal özellikleri üzerindeki etkileri [The effect of science education that is supported by scientific stories on students' creativity and affective properties]. Unpublished master's thesis, Hacettepe University, Ankara.

Günel, M. (2009). Bilimsel süreç ve ilköğretim bilim eğitiminde öğrenme arac1 olarak yazma [Writing as a Cognitive Process and Learning Tool in Elementary Science Education]. Elementary Online, 8(1), 200-211,

Günel, M., Kabataş Memiş, E., \& Büyükkasap, E. (2009). Öğrenme amaçlı yazma aktivitelerinin ve analoji kurmanın üniversite düzeyinde mekanik konularını öğrenmeye etkisinin incelenmesi [The effects of writing to learn activities and students' analogy construction on learning mechanic unit at the university level]. GÜ, Gazi Eğitim Fakültesi Dergisi [GU, Journal of Gari Education Faculty], 29(2), 401-419.
Günel, M., Kabataş Memiş, E., \& Büyükkasap, E. (2010). Yaparak yazarak bilim öğrenimi - yybö yaklaşımının ilköğretim öğrencilerinin fen akademik başarısına ve fen ve teknoloji dersine yönelik tutumuna etkisi [Effects of the science writing heuristic approach on primary school students' science achievement and attitude toward science course]. Eğitim ve Bilim [Education and Science], 35(155), 49-62.

Güneş, T., Dilek, N. Ş., Hoplan, M., Çelikoğlu, M., \& Demir, E. S. (2010, November). Öğretmenlerin alternatif değerlendirme konusundaki görüşleri ve yaptıkları uygulamalar [Teachers' opinions on alternative assessment and their applications]. In the Proceedings of International Conference on New Trends in Education and Their Implications (pp. 11-13).

Jara-Guerrero, S. (1993). Misconceptions on heat and temperature. In the Proceedings of the Third International Seminar on Misconceptions and Educational Strategies in Science and Mathematics. Ithaca: Misconceptions Trust.

Kalın, B. (2008). Üniversite ögrencilerinin çözeltiler konusundaki kavram yanilgilar [Misconceptions possessed by undergraduate students about the subject "solutions"]. Unpublished master's thesis, Balıkesir University, Balıkesir.

Kalın, B., \& Arıkıl, G. (2010). Çözeltiler konusunda üniversite öğrencilerinin sahip olduğu kavram yanılgiları [Misconceptions of undergraduate students about the topic "solutions"]. Necatibey Faculty of Education Electronic Journal of Science and Mathematics Education, 4(2), 177-206.

Karaçam, S., \& Gürsel, Ü. (2017). Lise öğrencilerinin sıvılarda kaldırma kuvveti kavramına yönelik görsel imgeleri ve imgenin kökenleri [High school students' visual images about the concept of buoyancy and roots of those images]. Mehmet Akif Ersoy Üniversitesi Ë̈itim Fakültesi Dergisi Mehmet Akif Ersoy University Journal of Faculty of Education], 1(41), 326-345.

Kırtak Ad, V.N. (2016). Tam stüdyo modelinin fen bilgisi ögretmen adaylarmmn kavramsal anlamalar ile sosyal duygusal ögrenme, sorgulama ve bilimsel süres becerilerine etkisi: akuş̧kanlar mekaniği örneği [The effect of full studio model on pre-service primary science teachers' conceptual understanding, social emotional learning, inquiry and science process skills: An example of fluid mechanics]. Unpublished doctoral dissertation, Balıkesir University, Balıkesir.

Kırtak Ad, V. N., \& Kocakülah, M. S. (2017). Debi ve süreklilik denklemi ile ilgili kavram yanılgılarının belirlenmesi [Determination of misconceptions on flow rate and continuity equation)]. Fen Bilimleri Öğretimi Dergisi [Science Teaching Journal], 5(2), 111-129.

Kocakülah, M. S. (1999). A study of the development of Turkish first year university students' understanding of electromagnetism and the implications for instruction. Unpublished doctoral dissertation, The University of Leeds School of Education, Leeds.

Leach, J., \& Scott, P. (2002). Designing and evaluating science teaching sequences: an approach drawing upon the concept of learning demand and a social constructivist perspective on learning. Studies in Science Education, 38, 115-142.

Leite, L., Mendoza, J., \& Borsese, A. (2007). Teachers' and prospective teachers' explanations of liquid-state phenomena: a comparative study involving three European countries. Journal of Research in Science Teaching, 44(2), 349-374.

Maass, S., \& Krause, S. J. (2014). The effect of incorporating youtube videos into an intervention addressing students' misconceptions related to solutions, solubility, and saturation. Paperpresented at 121 st ASEE Annual Conference \& Exposition.

Miles, M. B., \& Huberman, A. M. (1994). Qualitative data analysis an expanded sourcebook ( $2^{\text {nd }} \mathrm{Ed}$.). California: Sage Publications.

Ministry of National Education [MoNE]. (2018a). Fen bilimleri dersi öğretim programı (İlkokul ve ortaokul 3, 4, 5, 6, 7 ve 8. sınıflar) [Science course teaching program (Primary and middle school grades 3, 4, 5, 6, 7 and 8)]. Ankara.

Ministry of National Education [MoNE]. (2018b). Ortaöğretim kimya dersi öğretim programı $(9,10,11$ ve 12 . sinıflar) [Secondary level chemistry teaching program (Grades 9, 10, 11 ve 12]. Ankara. 
Mortimer, C. E. (1997). Modern üniversite kimyası [Modern university chemistry]. (T. Altınata et al., Trans.). İstanbul: Çağlayan Basımevi.

Nakleh, M. B. (1992). Why some students don't learn chemistry. Journal of Chemical Education, 69(3), 191-196.

Ok, M. (2019). Ögrrenci ve ögretmen adaylarmm sivnlar konusuna ilişkin düşünce biçimlerinin çoklu model kullanimula belirlenmesi Determining the ways of thinking of students and preservice teachers on liquids by using multiple models]. Unpublished master's thesis, Marmara University, İstanbul.

Özdemir, O. A., Merve, Ok., \& Kabapınar, F. (2021). Lise öğrencilerinin kimya dersi sıvılar konusuna ilişkin bilgilerinin çoklu gösterimler ile belirlenmesi [Determination of high school students' chemistry knowledge on liquids via multiple represantations]. Muğla Satke Kocman Üniversitesi Eğitim Fakültesi Dergisi [Muğla Sitke Kocman Üniversity Journal of Faculty of Education], 8(1), 250-273.

Özpolat, V. (2013). The place of student-centered approach in teachers' occupational priorities. Milli Eğitim Dergisi JJournal of National Education7, 200, 5-27.

Petrucci, R. H., Herring, F. G., Madura, J. D., \& Bissonnette, C. (2012). Genel kimya: Illkeler ve modern uygulamalar cilt 1 [General chemistry: Principles and modern applications volume 17 (T. Uyar, S. Aksoy \& R. İnam, Trans.). Ankara: Palme Yayıncilik.

Pınarbaşı, T., Sözbilir, M., \& Canpolat, N. (2009). Prospective chemistry teachers' misconceptions about colligative properties: boiling point elevation and freezing point depression. Chemistry Education Research and Practice, 10, 273-280.

Polat, M., \& Taşar, M. F. (2013). Bilimin doğası hakkındaki görüşlerin değerlendirilmesinde alternatif bir yöntem: Kısa hikâyeler yöntemi [An alternative technique for evaluating the opinions related to nature of science: Short story technique]. Mersin Üniversitesi Eğitim Fakültesi Dergisi [Mersin University Journal of Faculty of Education], 9(2), 259-274.

Rose, J. A. (2017). To teach science, tell stories. Project Master of Arts in the Graduate Liberal Studies Program in the Graduate School: Department of Biology, Duke University.

Sarıkaya, Y. (2011). Fizikokimya [Physicochemistry] (10 th Ed.). Ankara: Gazi Kitabevi.

Şahin, F. (2013). 8. smifögrencilerinin kaldrrma kuvveti konusundaki kavramsal anlamalarmin incelenmesi [Examination of the $8^{\text {th }}$ grade students' conceptual understandings about buoyancu force]. Unpublished master's thesis, Balıkesir University, Balıkesir.

Taber, K. S. (2019). The nature of the chemical concept: Re-constructing chemical knowledge in teaching and learning. Cambridge: Royal Society of Chemistry.

Tao, P. K. (2002). A study of students' focal awareness when studying science stories designed for fostering understanding of the nature of science. Research in Science Education, 32, 97-120.

Thomaz, M. F., Malaquias, I. M., Valente, M. C., \& Antunes, M. J. (1995). An attempt to overcome alternative conceptions related to heat and temperature. Physics Education, 30, 19-26.

Thompson, F., \& Logue, S. (2006). An exploration of common student misconceptions in science. International Education Journal, 7(4), 553559.

Tsaparlis, G. (2016). Problems and solutions in chemistry education. Journal of the Turkish Chemical Society Chemistry Education: Section C, 1(1), 1-30.

Yağbasan, R., \& Gülçiçek, Ç. (2003). Fen öğretiminde kavram yanılgilarının karakteristiklerinin tanımlanması Describing the characteristics of misconceptions in science teaching]. Pamukkale Üniversitesi Eğitim Fakültesi Dergisi [Pamukekale University Journal of Education Faculty], 13(1), 102-120.

Yıldırım, A., \& Şimşek, H. (2016). Sosyal bilimlerde nitel araştırma yöntemleri Qualitative research methods in social studies]. Ankara: Seçkin.

Yurdabakan, İ. (2011). Yapılandırmacı kuramın değerlendirmeye bakışı: Eğitimde alternatif değerlendirme yöntemleri [The view of constructivist theory on assessment: Alternative assessment methods in education]. Ankara Üniversitesi Eğitim Bilimleri Fakültesi Dergisi [Ankara University Journal of Faculty of Educational Sciences], 44(1), 51-78. 